\title{
ASYMPTOMATIC URINARY TRACT INFECTION AMONG PREGNANT WOMEN RECEIVING ANTE-NATAL CARE IN A TRADITIONAL BIRTH HOME IN BENIN CITY, NIGERIA
}

\author{
Bankole H. Oladeinde ${ }^{1}$, Richard Omoregie ${ }^{2}$, Oladapo. B. Oladeinde ${ }^{3}$
}

ABSTRACT

BACKGROUND: A good proportion of pregnant women patronize traditional birth homes in Nigeria for ante-natal care. This study aimed at determining the prevalence, risk factors, and susceptibility profile of etiologic agents of urinary tract infection among ante-natal attendees in a traditional birth home in Benin City, Nigeria.

METHODS: Clean-catch urine was collected from 220 pregnant women attending a traditional birth home in Benin City, Nigeria. Urine samples were processed, and microbial isolates identified using standard bacteriological procedures. A cross-sectional study design was used.

RESULTS: The prevalence of urinary tract infection among pregnant women was $55.0 \%$, significantly affected by parity and gestational age $(P<0.05)$. Mixed infection was recorded among $13(10.7 \%)$ pregnant women, and was unaffected by maternal age, parity, gravidity, gestational age, and educational status. Irrespective of trimester Escherichia coli was the most prevalent etiologic agent of urinary tract infection, followed by Staphylococcus aureus. The flouroquinolones were the most effective antibacterial agents, while Sulphamethoxazole-trimetoprim, Amoxicillin, Nalidixic acid, and Nitrofurantoin had poor activity against uropathogens isolated.

CONCLUSIONS: The prevalence of urinary tract infection among pregnant women was 55.0\% and significantly affected by gestational age and parity. The most prevalent etiologic agent observed was Escherichia coli. With the exception of the flouroquinolones, aminoglycoside, and Amoxicillincluvanate, the activity of other antibiotics used on uropathogens were poor. Health education of the traditional birth attendant and her clients by relevant intervention agencies is strongly advocated.

KEYWORDS: Urinary tract infection, pregnancy, orthodox birth center, traditional birth center, Nigeria

DOI: http://dx.doi.org/10.4314/ejhs.v25i1.2

\section{INTRODUCTION}

Urinary tract infection remains a leading cause of health care expenditure for people of all age groups (1). It is a serious health problem especially for women as up to a third of all women experience urinary tract infection at some point in their lives (2). Although often asymptomatic (3), the association of urinary tract infection with pregnancy could progress to symptomatic bacteriuria with fatal obstetric consequences such as pylonephritis, low birth weights and very high mortality rates (4).

\footnotetext{
${ }^{1}$ Department of Medical Microbiology, College of Health Sciences, Igbinedion University, Okada, Edo State, Nigeria

${ }^{2}$ School of Medical Laboratory Sciences, University of Benin Teaching Hospital, P.M.B 1111, Benin City, Edo State, Nigeria

${ }^{3}$ Department of Obstetric and Gyneocology, Irrua Specialist Teaching Hospital, Irrua, Edo State, Nigeria

Corresponding Author: Bankole Henry Oladeinde, Email: bamenzy@yahoo.com
} 
In Nigeria, a good proportion of indigenous women patronize traditional and religious birth homes for antenatal care (5). The traditional birth attendant (TBA) apart from being known to provide care for women during pregnancy $(6,7)$, presently deliver the majority of women in Nigeria as in other developing countries (6). Antenatal education promotes better pregnancy outcome and care for neonates $(8,9)$. This service is poor in traditional birth homes as the traditional birth attendants have been reported to be largely uneducated (10). They may therefore not be rightly placed to pass valuable information on disease prevention to their clients. This service is poor in traditional birth homes as the traditional birth attendants have been reported to be largely uneducated (10). They may therefore not be rightly placed to pass valuable information on disease prevention to their clients. Studies have shown in developing countries that a woman's level of education is a major determinant of her health seeking behavior $(11,12)$. Poverty and low educational status have been linked with patronage and delivery of pregnant women by traditional birth attendants $(13,14)$. These factors have also been shown to be associated with urinary tract infection in pregnancy (15). Although data on prevalence of asymptomatic urinary tract infection among pregnant women abound, to the best of our knowledge, none have focused on pregnant women receiving ante-natal care in traditional birth homes. With this background, this study therefore focused on determining the prevalence, risk factors, and susceptibility profile of etiologic agents, of urinary tract infection among pregnant women attending ante-natal clinics in a traditional birth home in Benin City, Nigeria

\section{METHODS AND PATIENTS}

Study population: A cross-sectional study was conducted between June 2011 to November 2011 among pregnant women attending ante-natal clinics at a leading traditional birth center in Benin City, Nigeria.

A total of two hundred and twenty (220) pregnant women with age ranging from (17-39) years were recruited for this study. Pregnant women who received ante-natal care in an orthodox birth facility were not considered for this study. Exclusion criteria also included usage of antibiotics within a week and large intake of water (less than an hour) before clinic attendance. Sociodemographic data were obtained by means of personal interview. Verbal informed consent was obtained from all pregnant women and their spouses. Approval for this work was given by Edo State Ministry of Health, Benin City.

Specimen collection and processing: Cleancatch midstream urine was collected from each patient into sterile screw-capped universal container, containing few crystals of boric acid as preservative. The specimen was mixed, labeled and transported to the laboratory for processing within one hour.

A loopful $(0.001 \mathrm{~mL})$ of well mixed uncentrifuged urine was streaked on to the surface of blood agar and cysteine lactose electrolyte deficient medium (CLED) medium (M6: Plasmatec Laboratories, United Kingdom). The plates were incubated aerobically at $37{ }^{\circ} \mathrm{C}$ for 24 hrs, and counts were expressed as colony forming units (CFU per mililitre $(\mathrm{mL})$. A count $\geq 10^{5}$ was considered significant to indicate urinary tract infection.

Ten $\mathrm{ml}$ of each well -mixed urine sample was centrifuged at $2000 \mathrm{~g}$ for 5 minutes. The supernatant was discarded and a drop of the deposit was examined microscopically at high magnification for pus cells, epithelial cells, cast, crystals, yeast-like cells, and trichomonas vaginalis. Pus cells $\geq 5$ per high power field were considered significant to indicate infection. Urinary tract infection was diagnosed, if the bacteria, or pus cell count or both were significant in an individual. The isolates were identified by standard microbiological methods (16). The susceptibility test for bacterial isolates was performed by BSAC method (17).

Statistical analysis: The data were analyzed using Chi-square $\left(\mathrm{X}^{2}\right)$ test, with the statistical software INSTAT ®.Statistical significance was set at $\mathrm{P}<$ 0.05 .

\section{RESULTS}

Significant bacteria growth was recorded in urine specimen from a total of one hundred and twenty one pregnant women representing $(55.0 \%)$ of all pregnant women studied. Out of the 121 positive cultures, 108(89.3\%) had single microbial growth 
while $13(10.7 \%)$ had more than one organism. Parity and gestational age were significant risk factors for acquiring urinary tract infection among pregnant women $(\mathrm{P}<0.05)$. Maternal age, parity, gravidity, gestational age and educational did not significantly affect the prevalence of mixed infection $(\mathrm{P}>0.05)$.

Irrespective of trimester, Escherichia coil was the most predominant etiologic agent of urinary tract infection, followed by Staphylococcus aureus. Candida albicans was the only fungi isolated in this study. (Table 2). While the flouroquinolones were the most effective antibacterial agents, Sulphamethoxazoletrimetoprim, Amoxicillin, Nalidixic acid, and Nitrofurantoin, all had poor activity against uropathogens from pregnant women studied (Table 3).

Table 1: Prevalence and risk factors among of urinary tract infection among pregnant women

\begin{tabular}{|c|c|c|c|c|}
\hline Characteristics & $\mathrm{N}$ & № infected (\%) & № mixed infection (\%) & $\mathrm{P}$ \\
\hline \multicolumn{5}{|l|}{ Parity } \\
\hline Nulliparous & 105 & $43(40.9)$ & $3(6.7)$ & \multirow{4}{*}{$0.0003,0.610^{*}$} \\
\hline Primiparous & 70 & $47(67.1)$ & $6(12.8)$ & \\
\hline Multiparous & 45 & $31(68.8)$ & $4(12.9)$ & \\
\hline Gravidity & & & & \\
\hline Primigravidae & 28 & $11(39.3)$ & $1(9.1)$ & \multirow[t]{2}{*}{$0.482,0.876^{*}$} \\
\hline Multigravidae & 192 & $10(57.3)$ & $12(10.9)$ & \\
\hline \multicolumn{5}{|l|}{ Gestational age } \\
\hline $1^{\text {st }}$ Trimester & 36 & $15(41.7)$ & $2(13.3)$ & \multirow{3}{*}{$0.006,0.872 *$} \\
\hline $2^{\text {nd }}$ Trimester & 96 & $48(50.0)$ & $4(8.3)$ & \\
\hline $3^{\text {rd }}$ Trimester & 88 & $58(65.9)$ & $7(12.1)$ & \\
\hline \multicolumn{5}{|l|}{ Educational status } \\
\hline Tertiary & 24 & $9(37.5)$ & $0(0.0)$ & \multirow[t]{4}{*}{$0.205,0.070^{*}$} \\
\hline Secondary & 117 & $66(56.4)$ & $4(6.1)$ & \\
\hline Primary & 47 & $25(53.2)$ & $4(16.0)$ & \\
\hline None & 32 & $21(65.6)$ & $5(23.8)$ & \\
\hline \multicolumn{5}{|l|}{ Age (Years) } \\
\hline $16-20$ & 15 & $1(6.6)$ & $0(0.0)$ & \multirow{5}{*}{$0.051,0.461 *$} \\
\hline $21-25$ & 44 & $3(52.3)$ & $2(8.7)$ & \\
\hline $26-30$ & 110 & 67 (60.9) & $7(10.4)$ & \\
\hline $31-35$ & 35 & $25(71.4)$ & $3(12.0)$ & \\
\hline $36-40$ & 16 & $5(31.3)$ & $1(20.0)$ & \\
\hline
\end{tabular}

$\mathbf{N}$ - number tested; $\mathbf{P} *$ - $\mathbf{P}$ value mixed infection

Table 2: Prevalence of uropathogens among pregnant women

\begin{tabular}{lccc}
\hline Bacterial (n) & $\begin{array}{c}\mathbf{1}^{\text {st }} \text { Trimester } \\
\mathbf{N}(\boldsymbol{\%})\end{array}$ & $\begin{array}{c}\mathbf{2}^{\text {nd }} \mathbf{T r i m e s t e r} \\
\mathbf{N}(\boldsymbol{\%})\end{array}$ & $\begin{array}{c}\mathbf{3}^{\text {rd }} \text { Trimester } \\
\mathbf{N}(\boldsymbol{\%})\end{array}$ \\
\hline Escherichia coli (51) & $6(35.3)$ & $20(38.5)$ & $25(37.9)$ \\
Klebsiella spp (16) & $1(5.9)$ & $6(11.5)$ & $9(13.6)$ \\
Proteus spp (11) & $1(5.9)$ & $4(7.7)$ & $6(9.1)$ \\
Pseudomonas aeruginosa (14) & $2(11.8)$ & $6(11.5)$ & $6(9.1)$ \\
Staphylococus aureus (32) & $5(29.4)$ & $12(23.1)$ & $15(22.7)$ \\
Enterococuss feacalis (2) & - & $1(1.9)$ & $1(1.5)$ \\
Candida albicans $(9)$ & $2(11.8)$ & $3(5.8)$ & $4(6.1)$ \\
\hline Total & 17 & 52 & 66 \\
\hline
\end{tabular}

$\mathbf{N}$ - number of isolates 
Table 3: Antibiotic susceptibility pattern of uropathogens from pregnant women

Antibacterial agent $\mu \mathrm{g} / \mathrm{DISC}$

\begin{tabular}{|c|c|c|c|c|c|c|c|c|c|}
\hline Bacterial agents (n) & CIP & OFL & PEF & GEN & AUG & SXT & $\mathbf{A M X}$ & NA & NIT \\
\hline & (5) & (5) & (5) & (10) & (30) & (25) & (30) & (30) & (300) \\
\hline Escherichia coll (51) & $51(100)$ & $50(98.0)$ & $40(78.4)$ & $42(82.4)$ & $29(56.8)$ & $9(17.6)$ & $7(13.7)$ & $14(27.4)$ & $21(41.1)$ \\
\hline Klebsiella species (16) & $16(100)$ & $16(100)$ & $11(68.7)$ & $11(68.7)$ & $8(50.0)$ & $2(12.5)$ & $1(6.2)$ & $4(25.0)$ & $7(43.7)$ \\
\hline Proteus species (11) & 11(100) & 11(100) & $6(54.5)$ & $8(72.7)$ & $5(45.5)$ & $1(9.0)$ & $0(0)$ & $1(9.0)$ & $0(0)$ \\
\hline $\begin{array}{l}\text { Pseudomonas } \\
\text { Aeruginosa (14) }\end{array}$ & $10(71.4)$ & $8(57.1)$ & $6(42.8)$ & $5(35.7)$ & $0(0)$ & $0(0)$ & $0(0)$ & $0(0)$ & $0(0)$ \\
\hline Staphylococus aureus (32) & 2) $30(93.8)$ & $28(87.5)$ & $23(71.8)$ & $20(60.5)$ & $11(34.4)$ & $3(9.3)$ & $1(0)$ & $4(12.5)$ & $1(34.4)$ \\
\hline Enterococuss feacalis (2) & $2(100)$ & $2(100)$ & $2(100)$ & $2(100)$ & $1(50)$ & $0(0)$ & $0(0)$ & $0(0)$ & $1(50)$ \\
\hline Total & $120(95.2)$ & $115(91.3)$ & $88(69.8)$ & $88(69.8)$ & $54(42.9)$ & $15(11.9)$ & $9(7.1)$ & $23(18.3)$ & $40(31.7)$ \\
\hline
\end{tabular}

\section{DISCUSSION}

The health status of the pregnant woman attending unorthodox birth centers in Nigeria has been overlooked, even though studies suggest that a good number of pregnant women in the country deliver their babies outside modern health facilities (5, 6). Against this background, this study was carried out to determine the prevalence, risk factors and susceptibility profile of etiologic agents of urinary tract infection among pregnant women attending ante-natal clinics at a traditional birth home in Benin City, Nigeria. To the best of our knowledge, this is the first attempt aimed at assessing the prevalence of urinary tract infection among pregnant women receiving ante-natal care in traditional birth home.

The prevalence of urinary tract infection observed in our study population was $55.0 \%$. This is higher than reported figures in other African studies $(3,4)$. It is pertinent, however, to note that these studies were conducted among pregnant women attending ante-natal clinics in institutionalized health facilities were regular antenatal education is more likely to be offered. Parity and gestational age significantly affected the prevalence of urinary tract infection. These have been previously reported $(18,19,20)$. Pregnant women in the $3^{\text {rd }}$ trimester of current pregnancy and those having more than one child were mostly at risk of acquiring urinary tract infection. Several anatomical and hormonal changes in pregnant women lead to urethral dilation and urinary stasis which contribute to increased risk of developing UTI (21). Urinary stasis increases with advancing pregnancy (22). This coupled with bad clean up technique, further complicated by heavily distended belly of pregnant women in the $3^{\text {rd }}$ trimester may well explain the high prevalence of urinary tract infection observed among pregnant women in the $3^{\text {rd }}$ trimester of pregnancy. Gravidity, maternal age and educational status did not affect the prevalence of urinary tract infection. This is consistent with previous findings $(23,24)$. The prevalence of mixed infection was not associated with maternal age, parity, gravidity, gestational age and educational status of pregnant women.

Escherichia coli was the most prevalent etiologic agent of urinary tract infection among pregnant women studied. The leading role of Escherichia coliin urinary tract infection among 
pregnant women has been severally documented $(3,4)$. It is, however, in contrast with other findings (15, 19). Irrespective of trimester, Escherichia coli was the most prevalent etiologic agent of urinary tract infection. The flouroquinolones were the most active antibacterial agent observed in this study. Sadly, however, these antibiotics have limited use in pregnancy. Moderate activity against bacterial isolates was observed with Gentimycin, and Amoxicillin-cluvanate, while very poor performance of Nitrofurantoin, Nalidixic acid, Amoxicillin and Sulphamethoxazole-Trimetoprim was recorded against uropathogens isolated from this study. Prescription of antibiotics without laboratory guidance as well as over-the-counter sales of antibiotics without prescription is rife in Nigeria, and has been adduced as a possible reasons for increased bacterial resistance to antimicrobial agents in the country. (25).

In conclusion, the prevalence of urinary tract infection among pregnant women was $55.0 \%$, and was significantly affected by parity and gestational age. Escherichia coli was the most prevalent etiologic agent of urinary tract infection among pregnant women. Poor to moderate antimicrobial activity against uropathogens was observed with antibiotics used except for the flouroquinolones. Health education of ante-natal populations in traditional birth centers by government and other intervention agencies is strongly advocated.

\section{ACKMOWLEDGEMENT}

We sincerely thank all pregnant women who participated in this study, and the Edo State Ministry of Health, Benin City for approval to carry out this work.

\section{REFERENCES}

1. Vasquez V, Hand W1. Antibiotic susceptibility patterns of community -acquired urinary tract infection isolates from female patients on the US(Texas)-Mexico border. J Appl Res, 2004; 4(2); 321-326.

2. Morgan KL. Management of Urinary Tract Infections during pregnancy. Am J. Matern Child Nursing, 2004; 29: 254-258.

3. Imade PE, Izekor PE., Eghafona NO, Enabulele OI, Ophori E. Asymptomatic bacteriuria in pregnant women. North Am $J$ Med Sci, 2010; 2:263-266.

4. Turpin CA, Minkah B, Danso KA, Frimpong EH. Asymptomatic bacteriuria in pregnant women attending antenatal clinics at Komfo Anakye Teaching Hospital, Kumasi. Ghana. Ghana Med J, 2007; 41(1):20-29.

5. Idowu OA, Mafiana CF, Sotiloye D. Rhesus negative pregnant women in a traditional birth home in Abeokuta, Nigeria Afr J Biotechnol, 2003; 2 (8):241-243.

6. Ofili AN, Okojie L. Assessment of the role of Traditional birthattendants in maternal health care in Oredo Local Government Area, EdoState. Nigeria. J Comm Med Prim Health Care, 2005; 17(1): 55-56.

7. Nyanzi S, Mannah H, Walraven G. Traditional Birth Attendants in Rural Gambia: Beyond Health to Social cohesion Afr $J$ Reprod Health, 2007; 11(1):43-56.

8. Renkert and Nutbeam D. Opportunities to improve maternal health literacy through antenatal education: an exploratory study. Health Promot Int, 2001;16(4)381-388.

9. Abdel-Aziem AA, Duria AR, Ameer OA, Ishag A. Awareness of danger signs and nutritional education among pregnant women in Kassala, Eastern Sudan. Sudanese J Public Health, 2010; 5:179-181.

10. Sadoh AE, Ogungbe RO. Multiple fractures and latrogenic burns in a Newborn due to unskilled Delivery: A case Report. Afr J Reprod Health, 2008; 12(3): 197-206.

11. Babalola S, Fatusi A. Determinants of use of maternal health services in Nigeria-Looking beyond individual and household factors. BMC Preg ChildBirth, 2009; 9 :43-45.

12. Ndidi EP, Osaremen IG. Reasons given by pregnant women for late initiation of antenatal care in the Niger Delta. Nigeria.Ghana Med J, 2010; 44(2):47-51.

13. Opiah MM, Osayi TA, Afolayan JA, AdeyanjuAB, Ute AF. Factors influencing patronage of traditional birth attendants for delivery and newborn care in Amassoma community, Southern Ijaw Local government area. Bayelsa State. Bull Sci Assoc Nigeria, 2010; 29:27-32.

14. Siziya S, Muula AS, Rudatsikira E. Socioeconomic factors associated with delivery assisted by traditional birth attendants in Iraq, 
2000. BMC Int Health HumRights, 2009; 9:7 doi 10. 1186/1472-698x-9-7.

15. Dimetry SR, El-tokhy HM, Abdo N.M, Ebrahim MA, Eissa M. Urinary tract infection and adverse outcome of pregnancy. $J$ Egypt Public Health Assoc, 2007; 82(3-4):203-218.

16. Barrow Gl, Feltham RKA. Cowan and Steels manual for identification of medical bacteria ( $3^{\text {rd }}$ edition). Cambridge: CambridgeUniversity press 2003.

17. British Society For Antimicrobial Chemotherapy (BSAC): BSAC methods for antimicrobial susceptibility testing. Version 8.2009 .

18. Halder G, Munir A, Zehra N, Haider A. Risk factors of urinary tract infection in pregnancy. J Pakistan Med Assoc 2010; 60 (3): 213-216

19. Akinloye O, Ogbolu DO, Akinloye OM, Tery Alli OA. Asymptomatic bacteriuria of pregnancy in Ibadan, Nigeria: a re-assessment. Br J Biomed Sci, 2006; 63(3): 109-112.

20. Nworie A, Eze UA. Prevalence and etiologic agent of urinary tract infection in Pregnancy in
Abakiliki metropolis. Cont J Med Res, 2010; 4:18-23.

21. Le J, Briggs GG, McKeown A, Bustillo G. Urinary tract infections during pregnancy. Ann Pharmacother, 2004; 38(10):1692-701.

22. Moyo SJ. Aboud S, Kasubi M, Maselle SY. Bacterial isolates and drug susceptibility pattern of urinary tract infection among pregnant women at Mihimbili National Hospital in Tanzania. Tanzanian J Health Res, 2010; 12(4): 233-236

23. Kovavisarach E, Vichaipruck M, Kanjarahareutai S. Risk factors related to asymptomatic bacteriuria in pregnant women .J Med Assoc Thai, 2009; 9(5): 606-610.

24. Sheikh MA, Khan MS, Khatoon A, Arain GM. Incidence of urinary tract infection during pregnancy). East Mediterr Health J, 2000; 6(2-3):265-271.

25. Omoregie R, Eghafona NO. Urinary tract infection among asymptomatic HIV patients in Benin City. Nigeria. Br D J Biomed Sci, 2009; 166(4):190-193. 